\title{
Livelihood strategies and diversification amongst the poor: Evidence from South African household surveys
}

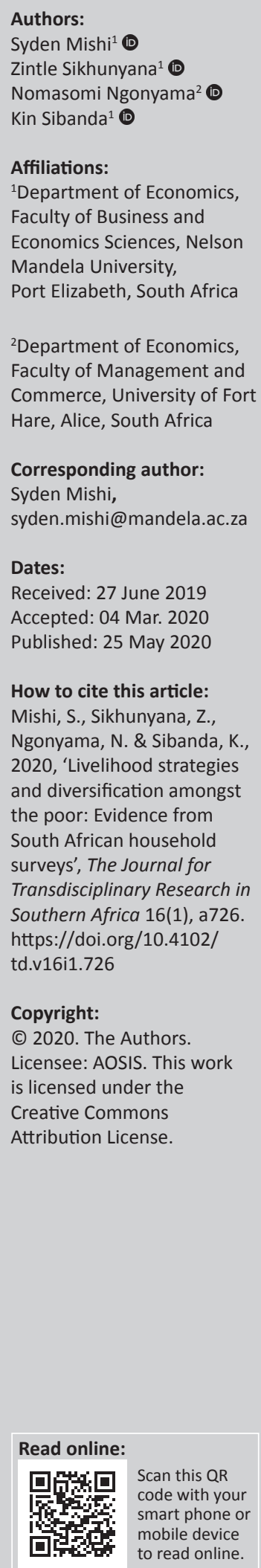

South Africa faces persistent challenges of poverty, unemployment and inequality. Recently, there has been growing literature trying to effectively address such challenges as the livelihood strategies of the poor need to be adequately understood. This article studied the livelihood strategies and diversification among the poor in South Africa using two data sets, namely the Statistics South Africa General Household Survey 2016 (GHS) and the Programme to Support Pro-poor Policy Development (PSPPD II)-University of Fort Hare (UFH) Economics survey. The study measured welfare using per capita income standardised by the adult equivalence scale (AES) which accounts for intra-household variations in members' access to household's resources and therefore corrects for economies of scale. Logistic regression techniques were employed to test the stated hypotheses. The GHS 2016-based results are in line with the sustainable livelihood framework, which posits that households need access to different sets of assets to sustain livelihoods. In this context, access to different assets has been shown to increase the probability of engaging in high-value strategies that will ensure sustainability of livelihoods. The PSPPD-UFH Economics data collaborate GHS-based results, showing that assets' access deprivation increases the odds of relying on non-labour income (like social grants) than engaging in high-value strategy (no farming income). Male-headed households and those with greater access to financial capital are more diversified.

Keywords: poverty; adult equivalence scale; transfer income; vulnerability; farming.

\section{Introduction and background}

About two-thirds of the world's poor people reside in the rural areas of low-income countries, mainly depending on subsistence farming and other natural resources for their livelihood (Aguilar \& Sumner 2020). Considering that there is very high rate of unemployment particularly in developing nations (International Labour Organization ILO 2018), entrepreneurship and household livelihood strategies can help to improve the standard of living of the poor, marginalised and unemployed (Alemu 2012; United Nations Food and Agriculture Organisation [UN-FAO] 2013). Rural people across nations no longer rely solely on agriculture but are engaging in a range of occupations to construct a diverse portfolio of livelihood activities (Alemu 2012). Households combine a set of activities such as agriculture, trade, informal employment, entrepreneurship and migration to achieve livelihood goals (Ellis 1998). However, goals of the rural households are not always achieved because of factors such as poor rainfall and lack of inputs, lack of funding and limited education, among other limitations especially around access to key assets (Blein 2013; Mishi \& Mudziwapasi 2014).

South Africa is battling persistently high levels of inequality (GINI coefficient ranging between 55 and 70); high unemployment rate (over a quarter of the labour force with that of the youths being over 50\%); high and severe poverty levels (Statistics South Africa 2018). Given the high levels of inequality, unemployment and poverty, improving access to key assets is crucial in order to enhance income generation for the majority of the rural poor. This makes an essential component of a successful rural development strategy in South Africa. According to Alemu (2012), labour endowment, age, education and community characteristics in terms of access to basic infrastructure are some of the barriers that poor households in rural areas face to enter into high-return livelihood strategies. South Africa is an interesting case study among the developing and emerging economies given the level of the three socio-economic ills mentioned above, which are significantly higher relative to peer economies. Data show that, for example, amongst the Brazil, Russia, India, China and South Africa (BRICS) group of countries, South Africa is the most unequal (Gini coefficients of the countries for 2018 stand at 51.3, 37.7, 35.1, 42.2 and 63, respectively) (World Bank 2018a), it is the one with the highest unemployment $(13.32 \%, 5.20 \%, 3.52 \%, 4.68 \%$ and $27.33 \%$, respectively) (World Bank 2018) and it is the one with the greatest proportion of individuals 
living in poverty $(8.7 \%, 13.2 \%, 21.9 \%, 3.1 \%$ and $55.5 \%$, respectively; including working poverty) (ILO 2018). Globally, South Africa is in the league of emerging economies, but in terms of development indicators, South Africa performs well below its peers as shown by the statistics mentioned above. The paradox is puzzling and has seen several programmes and policies being implemented, especially since the dawn of democracy from apartheid in 1994, albeit with limited evidence of effect.

There is limited evidence to show how rural households in developing and emerging economies, including South Africa, provide for and sustain their livelihoods (see few studies that have attempted this at a small-scale level: Alemu 2012; Carter \& May 1999; Leibbrandt, Woolard \& Woolard 2000; Mathebula et al. 2017). The results from such studies are inconsistent or leave gaps such as inabilities to properly articulate alternate strategies for livelihood, and ingrained diversification of income sources connected specifically to socio-cultural patterns in the South African society of neo-duality, especially in the rural communities. The challenges of South Africa differ in terms of severity across the nine regions (provinces ${ }^{1}$ ).

Eastern Cape is the poorest performing province in terms of education, having the lowest percentage of people with an education level higher than matric (Eastern Cape SocioEconomic Consultative Council [ECSECC] 2017). This is a function of both low educational quality within the province and the high outward migration of those with high educational attainment to other parts of the country. In terms of the Human Development Index, South Africa rates behind many of its 'poorer' neighbours, and the Eastern Cape lags the country as a whole, only ahead of Limpopo Province (Eastern Cape Non-Governmental Organisations [NGO] Coalition 2012). The people in the Eastern Cape Province are worse off than the people of South Africa in terms of overall development indicators. This is mostly because of a backlog in services, as well as fewer job opportunities in the rural areas.

Therefore, this article is aimed to identify livelihood strategies, investigate the determinants of livelihood strategies chosen by rural households and examine the extent to which rural households diversify their livelihood strategies. Barrett and Swallow (2005) argued that the analysis of livelihood strategies is more crucial for rural development policy. Analysis of historical, existing and possible livelihood strategies is crucial for understanding how people make economic decisions, and, in return, this could be used for achieving sustainable environmental management and development planning. Alemu (2012) argued that rural development intervention strategy requires economic policy-makers to have knowledge of what constitute the prevailing source of their livelihood strategies, why poor rural households are trapped into lower income activities and what policy interventions that can be followed to reduce rural poverty. One characteristic of the poor is involvement in diverse livelihood strategies for survival with limited option to identify one strategy to invest on (Ellis 1998). Diversification is a key to the survival of the poor and enables them to smooth consumption in the face of negative shocks (Ellis 1998).

It is imperative to note that in numerous cases the poor expend much on low-value activities and/or on the ones they do not enjoy competitive advantage on because of following other households within the community. This is explained by learning theory that individuals can watch what others (especially influential figures in the community) are doing and follow suit (Gautam \& Andersen 2016). With all these facts being stated, the study aims to provide information about livelihood strategies that can be targeted and incorporated by rural development policy-makers in decisions concerning poverty alleviation, employment creation and inequality reduction. The study makes use of two data sets: the official survey by the central statistics organisation (General Household Survey [GHS] 2016 version) and primary data collected through a project under the Programme to Support Pro-Poor Policy Development ${ }^{2}$ (PSPPD II) (Simatele, Mishi, Tsegaye, Makhetha-Kosi, Kapingura \& Khumalo, 2016). This triangulation of data allows for cross-pollination of evidence for better understanding the phenomenon under study.

\section{Literature Theoretical literature}

The study is underpinned by the New Institutional Economics theory. This theory explains how economic activities depend on social and legal norms and rules (Groenewegen, Spithoven \& Van den Berg 2010; Mishi \& Mudziwapasi 2014). For the households to derive livelihoods from an activity, utilising certain assets, it requires that such activity is socially acceptable and is legal. In addition, access and usage should be in line with the rules governing the jurisdiction in which the activities are to take place. An example is use of land, for example, in cultivation, one need to have legal access to the land and practice acceptable agricultural activities. In South Africa, the apartheid system differentiated the access and use of the different livelihood assets. The study therefore uses sustainable livelihood framework (SLF) and the asset-based community development (ABCD) framework to guide inquiry. These theoretical frameworks are critical in understanding the livelihoods strategies and diversification among the poor as discussed below.

\section{Sustainable livelihood approach}

Sustainable livelihood approach (SLA) is about empowerment of the most vulnerable and poor through strengthening of their capacity to achieve secure livelihoods. Chambers and Conway (1992) assert that:

[A] livelihood is sustainable if it is able to cope with and recover from shocks and stresses and be able to sustain its capabilities or assets now as well as in future. (p. 6)

2.Grant number: PSPPD2/CF. $2 / 2014 / 15 / 1$. 
Various communities have varied potentials and resources that can be exploited to promote sustainable livelihoods, and these include social, human, financial, natural and physical capitals.

Sustainable livelihood framework recognises that poor may not only need money but also need other material or non-material assets (Lloyd-Jones \& Rakodi 2002). For instance, they also require health, labour, knowledge and skills. Therefore, SLA is useful in understanding the dynamic relationship between the vulnerability context, local capacities and how people adopt various livelihood strategies. The SLA focuses on poor people as key actors in detecting and addressing livelihood challenges. The SLA should be responsive and participatory through building local processes and structures that support individuals to build their livelihoods upon their own strengths (Ashley \& Carney 1999). It then implies a bottom-up approach to development planning that considers local priorities, capacities and strengths in building resilient communities. In addition, understanding the key assets needed to establish and sustain livelihoods is critical in understanding how households will cope in the event of a shock, positive or negative (Mishi \& Mudziwapasi 2014).

\section{The asset-based community development approach}

This study is also informed by the ABCD approach. The $\mathrm{ABCD}$ approach considers local assets as the primary building blocks for sustainable livelihoods of the people. The ABCD approach captures assets inclusive of social, financial and physical assets (Mathie \& Cunningham 2003). The framework builds on the skills of residents, the strengths of local associations, the supportive functions of local institutions and the natural environmental endowments; hence, it draws upon existing community strengths to build more vibrant and sustainable communities. Development plans are fashioned so that of necessity they should impact on the livelihoods of those who are meant to benefit from it positively (Loison 2015).

Assets refer to the resources available to individuals, organisations or entire communities that can be used to further create wealth, reduce or prevent poverty, and redress skewed distribution (Wilke 2006). Broadly, assets may therefore be stocks that can be developed, transferred, managed and shared across generations. The focus on community assets, rather than her needs, represents a significant paradigm shift from a needs-based community development practice to assets-based development. This shift demands that development practitioners have a handle on the functioning dynamics of institutions and organisations as they interact socially among themselves and with the resources in the environment.

\section{Empirical literature}

Several studies have been conducted concerning livelihood strategies grouping (Alemu 2012; Maniriho \& Nilsson 2018;
Mukotami 2014; Munhenga 2014; Scoones 2016). Most of these studies have focused on migration, livelihood diversification and agricultural intensification. Some researchers explored different factors that determine the probability that farm household participates in non-agricultural income diversification activities and agriculture (Barrett, Reardon \& Webb 2001; Eneyew \& Bekele 2009; Geremew, Sangho \& Fellizah 2017). These researchers grouped livelihood strategies into three categories, namely farming activities, nonfarming activities and agriculture, while Alemu (2012) grouped livelihood strategies into four categories, namely non-labour, agriculture, off farming and non-farming. Grouping livelihood strategies enables easy analysis and comparisons as there are a multitude of economic activities that households may engage in, but with classification, the options become comparable.

Brown et al. (2006), Alemu (2012) and Leibbrandt et al. (2000) were interested in the factors that influence livelihood strategies. Brown et al. (2006) identified these factors as geographic, demographic and finance, while Alemu (2012) stressed that factors that influence livelihood strategies are age, gender (demographics) and assets endowments (related to finance in Brown et al. case). The two studies concur on the determinants. By the same token, it is of interest to understand what factors drive households to change from one strategy to another as in the case of Munhenga (2014). The focus of Munhenga (2014) was on households shifting from farm livelihood strategy to other livelihood strategies, and credit, remittances, market, distance, affiliation to cooperatives, education and house hold size were the driving factors.

On the other hand, Leibbrandt et al. (2000) examined the contributions of different household livelihood strategies on total income generated by each household, which is livelihood diversification. This determines which livelihood strategy is more rewarding to the household. Because of limited capitals, in the context of the SLF reviewed above, livelihood strategies engaged on by the poor are often of low reward. In that context, Maniriho and Nilsson (2018) as well as Urrehman, Jahanzeb and Rana (2008) recommended governments to provide professional training (human capital) and Internet access through wireless, increase investment in infrastructure (physical capital) and make loan policies favourable (financial capital) to support and sustain livelihood strategies.

It is apparent that households employ different strategies for livelihood, with each strategy potentially contributing differently from the other, depending on access to different capitals by a household. Literature has acknowledged that diversification of livelihood strategies emanates from unpredictability of shocks, trends in the economy and microeconomic logic of households depending on farming (Hussein \& Nelson 1999; Ellis 2000; Warren 2002). Carter and May (1999) assert that households whether they are poor or non-poor derive their livelihood strategies from diversified activities to reduce risks associated with shocks. The patterns of livelihood diversification depend upon activities chosen 
based on how labour is remunerated (majority of poor household have access to human capital and labour in terms of quantity in most instances) and on the location of the activity (Mathebula et al. 2017). According to Reardon, Delgado and Matlon(1992), Bryceson (1996), Chambers (1997), Hussein and Nelson (1999), Ellis (2000) and Warren (2002), households derive their livelihood based on key assets available, and their ability to diversify their livelihoods also depends upon key assets availability. This implies that diversification as a strategy is good; however, it is not always possible for all households as the base assets are key.

In line with this thinking, Loison (2015) conducted a study on diversification of rural livelihood in sub-Saharan Africa. The findings showed that households with sufficient assets are able to diversify their livelihoods between farming and nonfarming activities. Guided by the sustainable livelihoods approach and survey data from farmers in the Three Gorges Reservoir area in China, Xu et al. (2015) focused on the factors that determine a household choice of livelihood strategy. The study provides a descriptive statistical analysis and ordinal logistic regression model that shows that close to $56 \%$ of households exhibit a low dependence on agriculture. The following variables had a significant influence on livelihood strategy: the maximum years of education of any household member, the age of the household head, the number of labourers in a household, household location and formal and informal social networks. Social capital is one of the cheapest capital in terms of financial outlays that are limited; however, it takes time to be established and developed as trust among people required interactions of time.

Ellis (1998) asserts that diversification is not only voluntary but also involuntary. Von Braun and Pandya-Lorch (1991) and Mathebula et al. (2017) stated that rural households diversify their livelihood strategies to minimise risk and to respond to shocks. On the other hand, Barrett et al. (2001) stated that a household diversifies its livelihoods because of push factors such as risk reduction and also pull factors such as increase in income generated. Khatiwada et al. (2017) investigated the livelihood strategies by rural households in rural Nepal, with the results showing that the majority (61\%) of the households diversified their income to non-farm sources. Land holding (natural capital), education, agriculture and skill training (human capital), access to credit (financial capital) and proximity to the road and market centre (physical capital) were the major influencing factors on the adoption of higher returning livelihood strategies. In the same vein, Geremew et al. (2017) investigated the factors that determine the probability that a farm household participates in nonagricultural income diversification activities in Ethiopia. Using logit econometric and seemingly unrelated regression (SUR) estimations, the study showed that institutional factors such as secured perception of land ownership (natural capital) and becoming membership in cooperatives (social capital) have significant influence on the probability of farm households' participation in non-agricultural activities.
Furthermore, Reardon et al. (1992), Bryceson (1996), Chambers (1997), Hussein and Nelson (1999), Ellis (2000) and Warren (2002) looked at livelihood diversification as a strategy for risk management. The basic argument was that diversification requires households to choose the second best alternative strategy source of income. The concluding remarks were that farmers consider risk reduction as more important than income given up in the process of diversification. On the other hand, Urrehman et al. (2008) investigated different livelihood strategies and the factors affecting the livelihood strategies in Abbottabad district, North-West Frontier Province (NWFP), Pakistan. The study shows that only $15.8 \%$ of the poorest households were having secondary income from other sources. The average or betteroff households were mostly depending on the government and private services, remittances from within the country and abroad, self-employment and farming. Majority (80.4\%) of the respondents were involved in secondary source of incomes, and hence, livelihood strategies were classified in diversified group.

Alemu (2012) sought to identify dominant livelihood strategies in rural South Africa applying two approaches stochastic dominance test and multinomial logistic regression. The study obtained the results that showed households who generate income from wage employment in non-farm and farm activities are better off than other households. The findings by Hosu and Mushunje (2013) on livelihood diversification showed that on-farm diversification can increase income and also reduce risks, whereas the study by Carter and May (1999) showed that even though households can derive their livelihood from different activities, wage income earners are better off than households depending on agriculture for income. In the case of Eastern Cape, South Africa, Toyin and Mushunje (2016) found that households do not diversify their livelihoods and that they rely upon government cash transfers. Maniriho and Nilsson (2018) identified determinants of income diversification among Rwandan households using unique panel data obtained from the Integrated Households Living Conditions Surveys of 2011 and 2014. The study applies a binary logit panel model to a representative sample of 3839 households across Rwanda controlling for latent household-specific factors. The results reveal that education, access to information and communications technology (ICT) and urban areas were among the most important factors that influenced livelihood diversification.

Literature therefore has a gap, in that the poor maybe the ones considered to have interest in diversifying livelihood strategies; however, they need to have access to key assets to do that and they are poor because they have limited assets. Furthermore, where there is government social security net, households, even if they are poor, do not want to diversify, maybe because the drive for diversification is more of risk reduction that increases wealth and income and transfers income acts as an insurance. 


\section{The approach and data}

The approach of this study was concurrent mixed methods with data, methods and researcher triangulation embedded to provide a better understanding of the livelihood strategies and diversification (Creswell 2014). Mixed methods involved the collection and analysis of both quantitative and qualitative data, while triangulation entailed use of secondary data (Stats SA GHS 2016 - Eastern Cape sample) and survey conducted between February and July 2016 across the Eastern Cape under the PSPPD II-University of Fort Hare (UFH) Economics project. Triangulation refers to the practice of using either multiple sources of data or multiple approaches to analysing data to enhance the credibility of a research study. This is important as it helps to increase one's confidence in the study findings. This is performed through the confirmation of a proposition using two or more independent measures. This ultimately helps to provide comprehensive picture of the findings that one approach cannot do. This study triangulated data sources by using GHS and PSPPD II-UFH Economics data sets as well as utilising different techniques in analysing the data.

\section{Ranking of rural livelihoods}

To be able to rank livelihood strategies, we calculated welfare of each household. As it is not apparent which strategy is superior, literature provides means of determining that through linking livelihood strategies to welfare (Organisation for Economic Co-operation and Development [OECD] 2011; Stifel 2010). For this study, following $\operatorname{OECD}(2008 ; 2011)$, we measured welfare using per capita income standardised by the adult equivalence scale (AES) that accounts for intrahousehold variations in members' access to household's resources. This is so because the needs of a household grow with each additional member but - because of economies of scale in consumption - not in a proportional way. The demand for housing space, electricity, for example, will not be four times as high for a household with four members than for a single person. With the help of equivalence scales, each household type in the population is assigned a value in proportion to its needs. The factors commonly considered to assign these values are the size of the household and the age of its members (whether they are adults or children). ${ }^{3}$ In this study, we used the square root technique of AES discounting which is applied by dividing household income with the square root of household size. This implies that, for instance, a household of four persons has needs twice as large as one composed of a single person. For South Africa, we have adopted the OECD measure because there is no own scale, as is the case with other countries.

After computing the standardised per capita income as discussed above, four quintiles have been devised for the variable. Strategies that account for households in top quintile are considered superior as they set the household in the rich category compared to strategies that define 3.See OECD (2008 and 2011) for more detail.
TABLE 1: Demographic characteristics of Eastern Cape sample from the General Household Survey 2016.

\begin{tabular}{lcc}
\hline Variable & Frequency & $\%$ \\
\hline Sex of household head & & \\
Male & 1510 & 49.79 \\
Female & 1523 & 50.21 \\
Total & 3033 & 100.00 \\
Geographic location & & \\
Urban & 1468 & 48.40 \\
Rural & 1566 & 51.60 \\
Total & 3033 & 100.00 \\
\hline
\end{tabular}

households in the lower quintiles. Stochastic dominance test is a method that is generally used to identify dominance of category if general descriptive analysis cannot tell. In this study, quintiles were able to classify the households without a doubt and therefore no need for stochastic dominance test.

The article is testing whether poor households have been constrained to access high-income strategies (similarly, what factors explain participation in high-income strategies compared to the inferior strategies). Households need to engage in superior strategies for better welfare and thus sustainable livelihoods. This is a powerful tool for this study to be able to identify the factors attributable to poor households' failed entry into superior strategies (or rather confine then to inferior strategies), thereby presenting an opportunity to tackle poverty and inequality.

\section{Analysis of general household survey}

The sample reflected that majority of households in the sample drawn from Eastern Cape are female-headed (50.21\%) and $49.79 \%$ of households are male-headed, as shown in Table 1. The sample contained 3033 households. The table also shows that most of the population resides in rural areas (51.6\%) with $48.4 \%$ residing in urban areas. This reflects the true structure of the province which is considered predominantly rural.

In addition, the province is predominantly rural (51.60\%). By Statistics South Africa definition, urban areas are municipalities designated as cities, everything else is rural there is no formal definition (Ministry of Rural Development and Land Reform [MoRDLR] 2009). This is the definition that was used in this study in comparison to the definition in Department of Land Affairs (DoLA) (1997) of defining rural as sparsely populated areas where people rely on farming and natural resources.

\section{Determining livelihood diversification patterns, factors affecting them and related constraints within Eastern Cape}

We hypothesised that poorer households engage in numerous low-value activities to sustain livelihoods, while high-income households tend to specialise in few high-value strategies. ${ }^{4}$

4.This category contains employment (formal or non-formal) and self-employment initiatives which may not really be high value currently, but the potential is compared with transfer income option. 
TABLE 2: Income sources.

\begin{tabular}{lcc}
\hline Income sources & Frequency & $\mathbf{\%}$ \\
\hline Labour income (earned income) & 1126 & 38.21 \\
Business income & 134 & 4.55 \\
Remittances & 296 & 10.04 \\
Pension & 86 & 2.92 \\
Grants & 1266 & 42.96 \\
Farming income & 5 & 0.17 \\
Other income & 13 & 0.44 \\
No income & 21 & 0.71 \\
\hline Total & $\mathbf{2 9 4 7}$ & $\mathbf{1 0 0}$ \\
\hline
\end{tabular}

Source: Based on information from: Statistics South Africa, 2016, General Household Survey, viewed n.d., from https://www.statssa.gov.za/publications/P0318/P03182016.pdf

TABLE 3: Livelihoods

\begin{tabular}{lcc}
\hline Livelihoods & Frequency & $\mathbf{\%}$ \\
\hline No income & 21 & 0.71 \\
Non-labour (unearned or transfer) income & 1648 & 55.92 \\
Farming & 5 & 0.17 \\
$\begin{array}{l}\text { Non-farming (labour other than farming } \\
\text { related) (labour or earned income) }\end{array}$ & 1273 & 43.20 \\
\hline
\end{tabular}

Source: Based on information from: Statistics South Africa, 2016, General Household Survey, viewed n.d., from https://www.statssa.gov.za/publications/P0318/P03182016.pdf

This assertion is supported by the literature with Huber et al. (2014), concluding that different economic activities are found in poor communities and more often are diverse (Huber 2014).

Livelihood strategies are depicted from the various sources of income. The GHS (2016) has the following categories: income from wages, salaries and commissions; income from own businesses; income from sales of farm produce and services; income from rents and interest; and finally, income from remittances, pensions and grants. Table 2 illustrates the different income sources. It should be noted that households engage in different activities, and the classification here is based on what households reported as main source of income.

Agriculture is the mainstay in poor communities to the extent that literature suggests that activities should be grouped as farm related and not with non-farm activities increasing over the recent past (Stifel 2010; Zerihun 2012). For the purpose of analysis, activities were re-grouped into non-labour (unearned or transfer income), farming, labour income (business and wages or salaries or commission earned) and non-farming as follows (Stifel 2010; Corral \& Reardon 2001).

Table 3 shows that most households in Eastern Cape are reliant on transfer or non-earned income with majority being social grants, followed by remittances. Very few households are engaging in farming as main activity, despite the region believed to be supportive of farming activities. Black Africans are concentrated in the non-labour category, with white people and mixed race concentrated in the non-farming income.

Majority of the households (55.97\%) derived their main source of income from non-labour (unearned or transfer income) of which grants account for $42.94 \%$, remittances $10.10 \%$ and pension $2.93 \%$. Earned income is the next dominant strategy representing $43.18 \%$ of the households (labour 38.34\%, business $4.57 \%$, other $0.27 \%$ ), and farming was a strategy of only $0.14 \%$ of the households. Farming could have been made less attractive by segregating apartheid policies which confined the black majority in non-arable areas.

As in Zerihun (2012), $25.17 \%$ of the sample are very poor (quintile 1), the majority contributor being those who rely on unearned income $(71.27 \%)$. Considering by welfare categories (the quintiles), all unearned income is in the majority poor $(32.05 \%+36.56 \%)$ and those relying on farm income are generally rich (all in quintiles 3 and 4), while only earned income category is rich in the majority ( $48.18 \%$ in quintile). As welfare increases, reliance on unearned income decreases, while reliance on farming income and earned income increases.

It is, however, ironic that $73 \%$ of pensioners are rich (8.73\%) of the rich households and $4.29 \%$ of the rich are grant recipients. However, it was observed that the majority of those who are rich are labour income-based households (78.25\%) which makes unearned income a superior strategy and demotes entrepreneurship third place $(6.09 \%)$ after pensioners.

\section{Logistic regression}

To determine the reasons why some households do not pursue superior livelihoods strategies, that is, factors that affect livelihood diversification patterns and possible barriers to better living, logistic regression has been implemented. This is motivated by the nature of the dependent variables, which is categorical (Kremelberg 2011).

The household decision to follow through a strategy is considered to be dependent upon a number of factors such as demographic characteristics of the households, asset endowments (SLA approach) and access to services among others. This is expressed functionally as:

$y_{i}=y_{i}\left(A_{i}\left(q_{i}\right)\right)$

Where $y_{i}$ is per capita income of household $i$ expressed as a function of livelihood strategies $A_{i}$ which are a function of other factors such as age, gender, ownership or access to assets, among other factors $\left(q_{i}\right)$. To determine the effects of $q_{i}$ on $A_{i^{\prime}}$, we model a multinomial regression with $N$ possible responses with probabilities $p_{1}, p_{1}, \ldots p_{N}$ as:

$\log _{e}=\left[\frac{P_{j i}}{P_{1 i}}\right]=q_{i} \beta_{j}$

Where $j=2,3, \ldots, N ; i=1,2,3, \ldots \mathrm{I}$, where $j$ is the observation index, $i$ is the number of observations, $q_{i}$ is the $i$ th observation on $1 \times K$ vector of predictor variables and $b_{j}$ is a $K \times 1$ vector of parameters.

In that sense, the probability that an observed household $(i)$ belongs to a livelihood strategy $(j)$ is given by:

$P_{1 i}=\frac{1}{1+\sum_{j=2}^{N} e^{q_{i} \beta_{j}}}$ 
While the probability that a household belongs to the other livelihood strategies is represented by:

$$
P_{j i}=\frac{e^{q_{i} n_{j}}}{1+\sum_{j=2}^{N} e^{q_{i} n_{j}}} j=2 \ldots N .
$$

The above theoretical expression is going to be applied to our data sets (GHS 2016) and PSPPD II Economics UFH Survey.

\section{Multinomial logistic regression}

This type of regression is for dependant categorical variables, with observed categories being three or more. In this study,

TABLE 4: Population grouping.

\begin{tabular}{|c|c|c|c|c|c|c|c|c|}
\hline \multirow[t]{2}{*}{ Population group } & \multicolumn{2}{|c|}{ Non-labour } & \multicolumn{2}{|c|}{ Farming } & \multicolumn{2}{|c|}{ Non-farming } & \multicolumn{2}{|c|}{ Total } \\
\hline & $n$ & $\%$ & $n$ & $\%$ & $n$ & $\%$ & $n$ & $\%$ \\
\hline Black people & 1529 & 59.77 & 4 & 0.16 & 1025 & 40.07 & 2558 & 100 \\
\hline Mixed race people & 72 & 37.89 & 0 & 0 & 118 & 62.11 & 190 & 100 \\
\hline $\begin{array}{l}\text { Indian and/or Asian } \\
\text { people }\end{array}$ & - & - & - & - & 6 & 100 & 6 & 100 \\
\hline White people & 47 & 27.33 & 1 & 0.58 & 124 & 72.09 & 172 & 100 \\
\hline
\end{tabular}

Source: Based on information from: Statistics South Africa, 2016, General Household Survey viewed n.d., from https://www.statssa.gov.za/publications/P0318/P03182016.pdf

TABLE 5: Sources of income.

\begin{tabular}{lcccc}
\hline Quartile & Unearned income & Farming & Earned income & Total \\
\hline 1 (Count) & 526 & 0 & 191 & 717 \\
Row (\%) & 73.36 & - & 26.64 & 100 \\
Column (\%) & 32.05 & - & 15.09 & 24.63 \\
2 & 600 & 0 & 138 & 738 \\
Row (\%) & 81.30 & - & 18.70 & 100 \\
Column (\%) & 36.56 & - & 10.90 & 25.35 \\
3 & 405 & 2 & 327 & 734 \\
Row (\%) & 55.18 & 0.27 & 44.55 & 100 \\
Column (\%) & 24.68 & 50.00 & 25.83 & 25.21 \\
4 & 110 & 2 & 610 & 722 \\
Row (\%) & 15.24 & 0.28 & 84.49 & 100 \\
Column (\%) & 6.70 & 50.00 & 48.18 & 24.80 \\
Total & 1641 & 4 & 1266 & 2911 \\
Row (\%) & 56.37 & 0.14 & 43.49 & 100 \\
Column (\%) & 100 & 100 & 100 & 100 \\
\hline Source Based & & & & \\
\hline
\end{tabular}

Source: Based on information from: Statistics South Africa, 2016, General Household Survey viewed n.d., from https://www.statssa.gov.za/publications/P0318/P03182016.pdf we have three categories of interest (unearned income, farming income and earned income), and no income category has been removed as it showed no livelihood strategy and skewed the data.

The data, as presented in Table 7, show that sex of head of household, ownership of assets (stove) and number of children are the factors that can predict farming strategy distinguishing it from non-labour strategy. The coefficients are converted to relative risk ratios (RRRs, i.e. odds ratios); therefore, we can conclude that the likelihood of relying on farming as compared to be non-labour (transfer income) reliant is 11.86 times for male- as for female-headed households.

Farming is considered high-value strategy across literature (see Huber et al. 2014; Stifel 2010), and the results imply that female-headed households are less likely to engage in such strategy. Female-headed households in Eastern Cape Province are therefore observed as constrained to improve their livelihoods. On the other hand, access to assets as proxied by owning basic household gadgets like electric stove makes a household 1.69 times more likely to be relying on farming than non-labour income.

Having more children in the household (under 17-year-old household members) makes the household 0.833 times likely (reduces the odds) to be relying on farming than non-labour income (social grant mainly and remittances). Children cannot work, and in South Africa, there is child support and foster grant that cater for children up to the age of 21 years. Therefore, households with more children are likely to be receiving more of state support and thus make non-labour income the greatest source of livelihood for the household. More of such grants are received, the more the parents are no gainfully earning elsewhere. The question that is often asked is that: is there over reliance on social grants, we will turn to this later?

The last column of the Table 7 reports the RRR in relation to the coefficients on non-farming income. Recall, non-farming

TABLE 6: Livelihood strategies as defined by income sources.

\begin{tabular}{|c|c|c|c|c|c|c|c|c|c|}
\hline Quartile & Labour & Business & Remittance & Pension & Grant & Farming & Other & No income & Total \\
\hline \multirow[t]{3}{*}{1} & 150 & 35 & 175 & 1 & 350 & 0 & 6 & 21 & 738 \\
\hline & 20.33 & 4.74 & 23.71 & 0.14 & 47.43 & 0.00 & 0.81 & 2.85 & 100.00 \\
\hline & 13.35 & 26.12 & 59.12 & 1.16 & 27.80 & 0.00 & 75.00 & 100.00 & 25.17 \\
\hline \multirow[t]{3}{*}{2} & 118 & 20 & 63 & 7 & 530 & 0 & 0 & 0 & 738 \\
\hline & 15.99 & 2.71 & 8.54 & 0.95 & 71.82 & 0.00 & 0.00 & 0.00 & 100.00 \\
\hline & 10.50 & 14.93 & 21.28 & 8.14 & 42.10 & 0.00 & 0.00 & 0.00 & 25.17 \\
\hline \multirow[t]{3}{*}{3} & 291 & 35 & 42 & 15 & 348 & 2 & 1 & 0 & 734 \\
\hline & 39.65 & 4.77 & 5.72 & 2.04 & 47.41 & 0.27 & 0.14 & 0.00 & 100.00 \\
\hline & 25.89 & 26.12 & 14.19 & 17.44 & 27.64 & 50.00 & 12.50 & 0.00 & 25.03 \\
\hline \multirow[t]{3}{*}{4} & 565 & 44 & 16 & 63 & 31 & 2 & 1 & 0 & 722 \\
\hline & 78.25 & 6.09 & 2.22 & 8.73 & 4.29 & 0.28 & 0.14 & 0.00 & 100.00 \\
\hline & 50.27 & 32.84 & 5.41 & 73.26 & 2.46 & 50.00 & 12.50 & 0.00 & 24.62 \\
\hline \multirow[t]{3}{*}{ Total } & 1124 & 134 & 296 & 86 & 1259 & 4 & 8 & 21 & 2932 \\
\hline & 38.34 & 4.57 & 10.10 & 2.93 & 42.94 & 0.14 & 0.27 & 0.72 & 100.00 \\
\hline & 100.00 & 100.00 & 100.00 & 100.00 & 100.00 & 100.00 & 100.00 & 100.00 & 100.00 \\
\hline
\end{tabular}

Source: Based on information from: Statistics South Africa, 2016, General Household Survey, viewed n.d., from https://www.statssa.gov.za/publications/P0318/P03182016.pdf 
TABLE 7: Multinomial regression: Livelihood strategies.

\begin{tabular}{|c|c|c|c|c|c|c|c|c|}
\hline \multirow[t]{2}{*}{ Variables } & \multicolumn{2}{|c|}{ Only-farm } & \multicolumn{2}{|r|}{ RRR } & \multicolumn{2}{|c|}{ Non-farm } & \multicolumn{2}{|c|}{ RRR } \\
\hline & Coefficient & Standard error & Coefficient & Standard error & Coefficient & Standard error & Coefficient & Standard error \\
\hline Mixed race people versus black people & -14.19 & 1764 & - & - & 0.188 & 0.206 & - & - \\
\hline $\begin{array}{l}\text { Indian people and/or Asian people versus black } \\
\text { people }\end{array}$ & 3.447 & 23325 & - & - & 17.60 & 6282 & - & - \\
\hline White people versus black people & -0.0852 & 2.655 & - & - & $0.647 * *$ & 0.259 & $1.910 * *$ & 0.495 \\
\hline head_sex-male & $2.473^{*}$ & 1.440 & $11.86^{*}$ & 17.06 & $0.763 * * *$ & 0.102 & $2.145 * * *$ & 0.218 \\
\hline head_age & 0.0923 & 0.0569 & - & - & -0.00469 & 0.00461 & - & - \\
\hline Bedrooms & 0.0417 & 0.0521 & - & - & 0.0179 & 0.0196 & - & - \\
\hline Electricity & -1.440 & 1.260 & - & - & $0.532 * * *$ & 0.179 & $1.703 * * *$ & 0.304 \\
\hline Cellphone & 0.183 & 1.287 & - & - & $0.675 * * *$ & 0.182 & $1.964 * * *$ & 0.357 \\
\hline Internet in house & 5.308 & 3.740 & - & - & $1.536 * * *$ & 0.375 & $4.647 * * *$ & 1.743 \\
\hline Computer ownership & -2.357 & 3.708 & - & - & $0.150 *$ & 0.0824 & $1.162 *$ & 0.098 \\
\hline Electric stove & $0.523 * *$ & 0.245 & $1.69 * *$ & 0.141 & $0.162 *$ & 0.0964 & $1.175^{*}$ & 0.081 \\
\hline Television & -1.298 & 1.665 & - & - & $0.226 * * *$ & 0.0778 & $1.254 * * *$ & 0.098 \\
\hline Children $<5$ years & -13.27 & 798.1 & - & - & 0.0173 & 0.0908 & - & - \\
\hline Children $<17$ years & -0.183 & 0.028 & $0.833^{*}$ & 0.559 & $-0.510 * * *$ & 0.0739 & $0.600 * * *$ & 0.044 \\
\hline Adults 60 years + & -1.247 & 1.182 & - & - & $-2.061 * * *$ & 0.143 & $0.127 * * *$ & 0.018 \\
\hline Disabled member & 0.581 & 0.704 & - & - & $-0.452 * * *$ & 0.0765 & $0.636 * * *$ & 0.049 \\
\hline Geo type-rural & -0.0520 & 1.405 & - & - & $-1.169 * * *$ & 0.107 & $0.311 * * *$ & 0.033 \\
\hline Diversified & 1.475 & 1.095 & - & - & $0.727 * * *$ & 0.109 & $2.07 * * *$ & 0.225 \\
\hline Constant & $-11.42 * * *$ & 4.025 & - & - & -0.377 & 0.303 & - & - \\
\hline Observations & 2920 & - & - & - & 2920 & - & - & - \\
\hline
\end{tabular}

Source: Based on information from: Statistics South Africa, 2016, General Household Survey, viewed n.d., from https://www.statssa.gov.za/publications/P0318/P03182016.pdf

RRR, relative risk ratios.

$*, p<0.1 ; * *, p<0.05 ; * * *, p<0.01$

income encompasses all labour- and business-related income other than what is linked to farming (Zerihun 2012). The results show that there are 14 factors that help classify households into non-farming income strategy compared to non-labour.

The factors are (in no specific order): race; sex of household head; access to electricity, cell phone, Internet, computer, electricity stove and TV; household size; number of children; number of adults over 60 years; presence of disabled household member; geographic type; rural versus urban; and whether the household is involved in other income source other than the main.

The results show that the likelihood of relying on nonfarming income (high value or superior strategy) compared with non-labour income (low value or inferior strategy) is 1.91 times high for white Africans than black Africans. In addition, being male-headed household increases the odds of relying on non-farming income by 2.15 times than relying on non-labour income, so is access to electricity (1.7 times higher), cell phone (1.96 times), Internet (4.65 times), computer (1.16 times), stove (1.18 times), TV (1.25 times), household size (1.18 times) and diversification (2.07 times). While having a disabled member, and more dependents (adults over 60 years, more children under 17 years), owning reduces the odds of relying on non-farming activities, but rather increases the dependency on non-labour income.

The results are in line with the SLF which posits that households need to access different sets of assets to sustain livelihoods. In this context, access to different assets has been shown to increase the probability of engaging in high-value strategies that will ensure sustainability of livelihoods. To summarise the five assets that can be proxied as follows from the statistically significant predictors: human capital (sex of head; race; household size, children, adults, disabilities), physical (cell phone, computer, stove, TV), financial (diversification) and social (electricity). The results are robust with likelihood ratio (LR) $\mathrm{chi}^{2}$ (38) of 1420.15, and the Prob $>\mathrm{Chi}^{2}$ being statistically significant at $1 \%$. In addition, the pseudo- $R^{2}$ is $35 \%$ and the Log likelihood is -1323.37 .

Figure 1 summarises the effect of welfare (based on per capita income quintiles) on livelihood strategy. The figure has panels a-d representing the four quintiles 1-4, respectively. In can be observed that the probability of someone engaging falling in quintile 1 (very poor) (see panel a) and quintile 2 (poor) (see panel b) is highest among unearned or non-labour reliant households. While probability of someone being in quintile 3 (see panel c) is high among farm income-reliant households and quintile 4 (shown by panel d) is highly predicted by both only farming income and non-farm income.

Furthermore, we were also interested in factors explaining welfare (an order logistic regression was carried out) as well as predictors of diversification and food security (skipped meals) through binary logistics regressions. Diversification is dichotomous with 1 when the households practice more than one of the livelihood strategies listed, else 0 . On the other hand, food security is 0 if the households did not skip any meal, while 1 resembles those households who have skipped a meal. Several factors have been found to explain these variables - see Table 8 . For each model, the coefficient and 


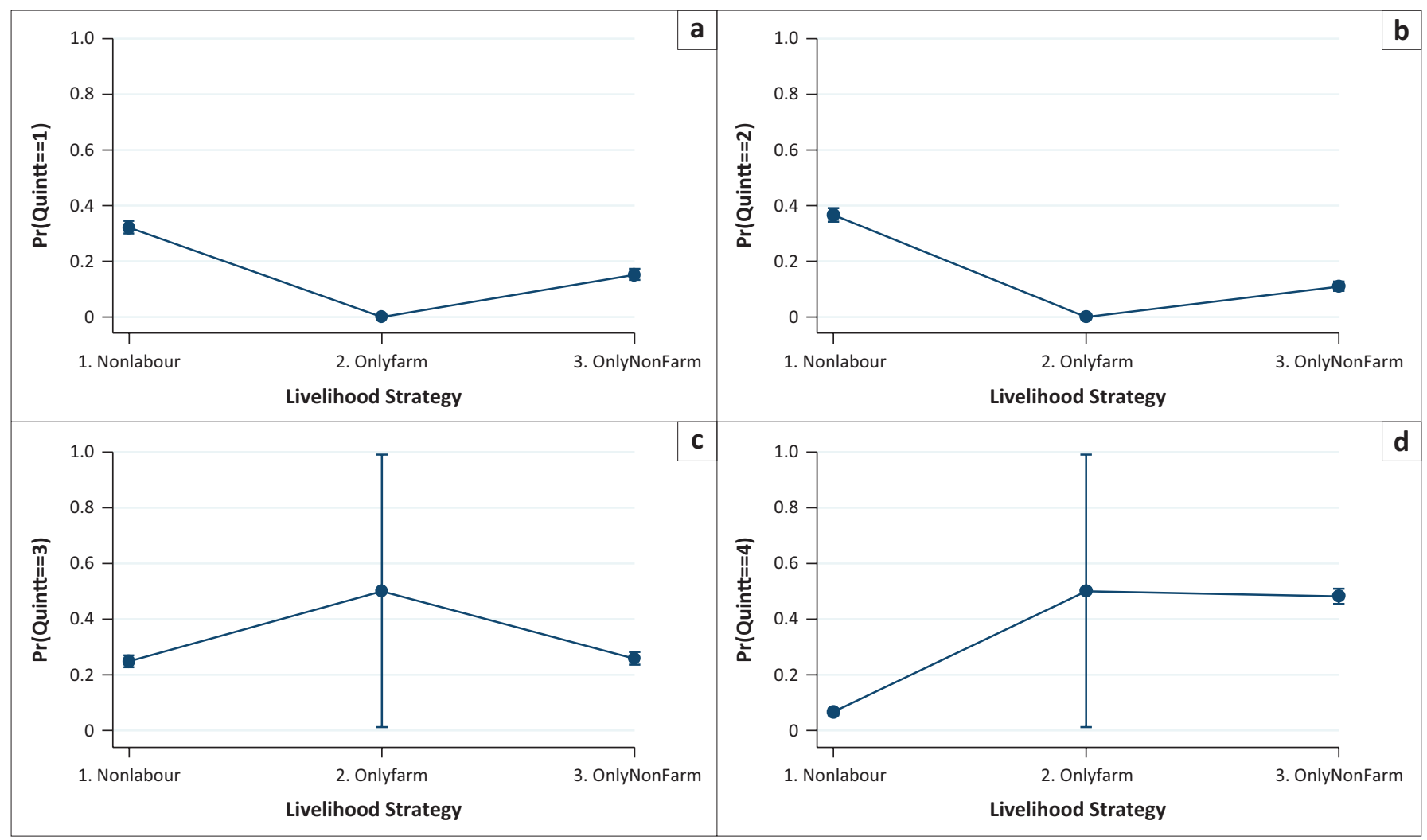

Source: Based on information from: Statistics South Africa, 2016, General Household Survey, viewed n.d., from https://www.statssa.gov.za/publications/P0318/P03182016.pdf FIGURE 1: Adjusted predictions of strategies with 95\% confidence intervals: (a) First quartile, (b) Second quartile, (c) Third quartile and (d) Fourth quartile.

corresponding odds ratio to be interpreted (for statistically significant coefficients only) are displayed. The results reflect those discussed under multinomial logistic.

Even though assets are critical for sustainability of livelihoods, it appears that owning a computer and TV increases the odds of skipping a meal. Those who own a computer are more likely to be not diversified but are likely to be falling in highincome category (higher per capita income quintile).

To provide reliable results, we did the diagnostics tests to check the robustness of the results. The diagnostics tests were to check and correct for specification errors, classification and multicollinearity. Table 9 presents the results of the diagnostic tests.

The first thing to do to remedy misspecification is to see if we have included all of the relevant variables - this was checked, and all possible predictors were in the model. Interaction terms were included, but the specification did not improve.

The overall rate of correct classification is estimated to be 65.94 , with $65.94 \%$ of the no diversification group correctly classified (specificity) and $62.87 \%$ of the diversified group correctly classified (sensitivity).

The multicollinearity results are measures of the strength of the interrelationships among the variables. Two commonly used measures are tolerance (an indicator of how much collinearity that a regression analysis can tolerate) and variance inflation factor (VIF - an indicator of how much of the inflation of the standard error could be caused by collinearity). If all of the variables are orthogonal to each other, in other words, completely uncorrelated with each other, VIF is 1 . If a variable is very closely related to another variable(s), the variance inflation gets very large. A standard VIF of 10 or greater is of concern.

Prediction power is tested through looking at area under the curve. The area under the receiver operating characteristic (ROC) curve can give us insight into the predictive ability of the model. Each point on the ROC curve represents a sensitivity or specificity pair corresponding to a specific decision threshold. If the value is equal to 0.5 , the model can be thought of as predicting at random. Higher values, approaching 1 , indicate that the model has good predictive ability. The results in Table 9 and Figures 2 and 3 show that our models have good predictive power.

\section{Programme to Support Pro-poor Policy Development II Survey}

The dependent variable is livelihood strategies and it is presented in Table 10.

The results show that deprivation increases the odds of relying on non-labour income (e.g. social grants) than engaging in high-value strategy (no farming income). A unit increase in deprivation, signifying more deprivation, results 
TABLE 8: Logistic regression.

\begin{tabular}{|c|c|c|c|c|c|c|c|c|c|c|c|c|}
\hline \multirow[t]{2}{*}{ Variables } & \multicolumn{4}{|c|}{ Welfare (ologit) } & \multicolumn{4}{|c|}{ Diversification (blogit) } & \multicolumn{4}{|c|}{ Food security (blogit) } \\
\hline & Coefficient & $\begin{array}{l}\text { Standard } \\
\text { error }\end{array}$ & OR & $\begin{array}{l}\text { Standard } \\
\text { error }\end{array}$ & Coefficient & $\begin{array}{l}\text { Standard } \\
\text { error }\end{array}$ & OR & $\begin{array}{l}\text { Standard } \\
\text { error }\end{array}$ & Coefficient & $\begin{array}{l}\text { Standard } \\
\text { error }\end{array}$ & OR & $\begin{array}{l}\text { Standard } \\
\text { error }\end{array}$ \\
\hline $\begin{array}{l}\text { Mixed race people versus } \\
\text { black people }\end{array}$ & $0.472 * * *$ & 0.1499 & $1.603 * * *$ & 0.2399 & 0.0773 & 0.162 & - & - & 0.0808 & 0.205 & - & - \\
\hline $\begin{array}{l}\text { Indian people or Asian } \\
\text { people versus black people }\end{array}$ & $2.668 * *$ & 1.150 & $14.417 * *$ & 16.584 & 0.575 & 0.787 & - & - & - & - & - & - \\
\hline White versus black people & $2.874 * * *$ & 0.329 & $17.700 * * *$ & 5.823 & $-0.649 * * *$ & 0.205 & $0.523 * * *$ & 0.107 & $-1.582 * * *$ & 0.530 & $0.206 * * *$ & 0.109 \\
\hline head_sex & $0.592 * * *$ & 0.0737 & $1.808 * * *$ & 0.133 & $-0.365 * * *$ & 0.0827 & $0.694 * * *$ & 0.057 & $-0.171 *$ & - & $0.842^{*}$ & - \\
\hline Bedrooms & $0.192 * * *$ & 0.0290 & $1.212 * * *$ & 0.035 & $0.0792 * *$ & 0.329 & $1.082 * *$ & 0.036 & $-0.0846 * *$ & 0.0416 & $0.919 * *$ & 0.038 \\
\hline Access to assets & $0.430 * * *$ & 0.114 & $1.537 * * *$ & 0.175 & 0.201 & 0.133 & - & - & -0.223 & 0.151 & - & - \\
\hline Cell phone & $0.854 * * *$ & 0.119 & $2.350 * * *$ & 0.280 & $0.464 * * *$ & 0.150 & $1.590 * * *$ & 0.239 & $-0.732 * * *$ & 0.154 & $0.481 * * *$ & 0.074 \\
\hline Internet in house & $2.196 * * *$ & 0.386 & $8.992 * * *$ & 3.472 & -0.102 & 0.236 & - & - & $-0.899 *$ & 0.493 & $0.407^{*}$ & 0.201 \\
\hline Computer & $0.221 * * *$ & 0.0771 & $1.247 * * *$ & 0.096 & $-0.115^{*}$ & 0.0685 & $0.891^{*}$ & 0.060 & $0.143^{*}$ & 0.0737 & $1.154 *$ & 0.085 \\
\hline Electric Stove & -0.0435 & 0.0505 & - & - & 0.0324 & 0.0564 & - & - & $0.126 * *$ & 0.0617 & $1.134 * *$ & 0.070 \\
\hline Television & 0.0795 & 0.0509 & - & - & 0.0412 & 0.0581 & - & - & $-0.470 * * *$ & 0.116 & $0.625 * * *$ & 0.073 \\
\hline Children $<5$ years & 0.0394 & 0.0394 & - & - & 0.0523 & 0.0700 & - & - & 0.0103 & 0.0795 & - & - \\
\hline Children $<17$ years & 0.0229 & 0.0475 & - & - & -0.0323 & 0.0544 & - & - & $-0.143 * *$ & 0.0636 & $0.867 * *$ & 0.551 \\
\hline Adults ( 60 years + ) & $0.472 * * *$ & 0.0812 & $1.603 * * *$ & 0.130 & $-0.223 * *$ & 0.0926 & $0.800 * *$ & 0.074 & $-0.682 * * *$ & 0.128 & $0.506 * * *$ & 0.065 \\
\hline Disabled member & -0.0670 & 0.0472 & - & - & -0.0237 & 0.0549 & - & - & 0.0256 & 0.0658 & - & - \\
\hline Geographic type & $-1.146 * * *$ & 0.0814 & $0.318 * * *$ & 0.026 & $-0.197 * *$ & 0.0902 & $0.821 * *$ & 0.074 & $0.334 * * *$ & 0.113 & $1.397 * * *$ & 0.157 \\
\hline Diversified & $0.671 * * *$ & 0.0751 & $1.955 * * *$ & 0.147 & - & - & - & - & -0.146 & 0.103 & - & - \\
\hline Constant cut1 & 0.291 & 0.211 & - & - & - & - & - & - & - & - & - & - \\
\hline Constant cut2 & $1.662 * * *$ & 0.213 & - & - & - & - & - & - & - & - & - & - \\
\hline Constant cut3 & $3.158 * * *$ & 0.218 & - & - & - & - & - & - & - & - & - & - \\
\hline Constant & - & - & - & - & $-1.718 * * *$ & 0.249 & - & - & $-0.720 * * *$ & 0.274 & - & - \\
\hline Observations & 3003 & - & - & - & 3027 & - & - & - & 3020 & - & - & - \\
\hline
\end{tabular}

Source: Based on information from: Statistics South Africa, 2016, General Household Survey, viewed n.d., from https://www.statssa.gov.za/publications/P0318/P03182016.pdf OR, Odds Ratio.

$*, p<0.1 ; * *, p<0.05 ; * * *, p<0.01$.

TABLE 9: Diagnostic tests.

\begin{tabular}{llll}
\hline Model & Diagnostic & Value & Decision \\
\hline Diversification & Specification error & 0.000 & $\begin{array}{l}\text { Meaningful predictors chosen } \\
\text { but misspecification error } \\
\text { exists }\end{array}$ \\
Food security & Specification error & 0.698 & $\begin{array}{l}\text { Meaningful predictors, correctly } \\
\text { specified }\end{array}$ \\
Diversification & Classification & $65.94 \%$ & $\begin{array}{l}\text { Correctly classified sizeable } \\
\text { proportion }\end{array}$ \\
Food security & Classification & $80.60 \%$ & $\begin{array}{l}\text { Correctly classified; great } \\
\text { proportion }\end{array}$ \\
Diversification & Multicollinearity & 2.01 & None \\
$\begin{array}{l}\text { Food security } \\
\text { Diversification }\end{array}$ & Multicollinearity & 1.96 & - \\
Food security & Prediction power & 0.7095 & - \\
\hline Source: Bastion power & 0.6913 & - \\
\hline
\end{tabular}

Source: Based on information from: Statistics South Africa, 2016, General Household Survey, viewed n.d., from https://www.statssa.gov.za/publications/P0318/P03182016.pdf

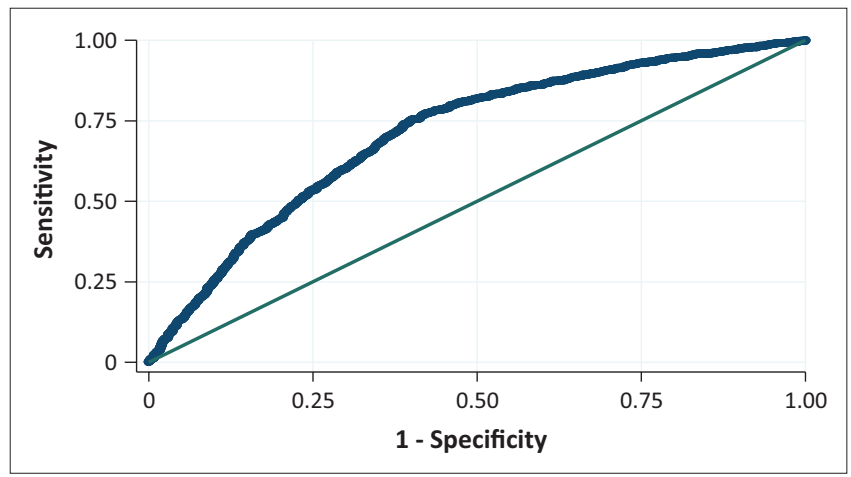

Source: Based on information from: Statistics South Africa, 2016, General Household Survey, viewed n.d., from https://www.statssa.gov.za/publications/P0318/P03182016.pdf Note: Area under ROC curve $=0.7095$.

ROC, receiver operating characteristic.

FIGURE 2: Receiver operating characteristic curve - Diversification model.

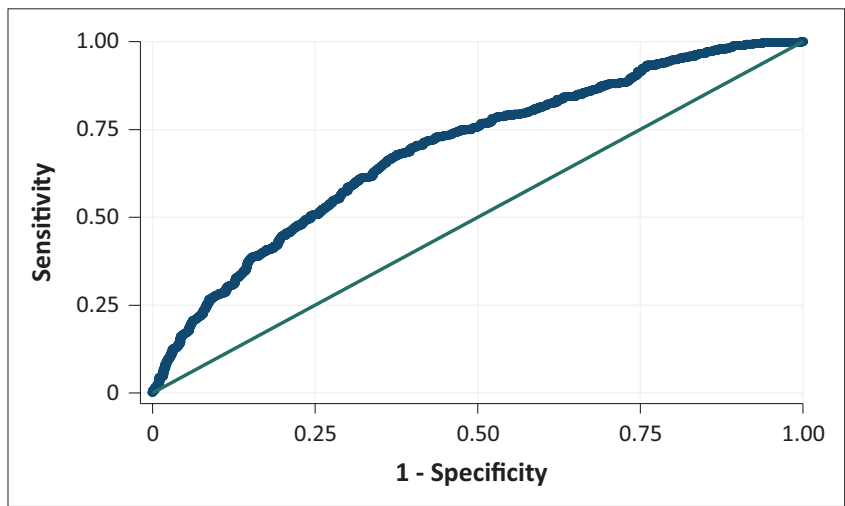

Source: Based on information from: Statistics South Africa, 2016, General Household Survey, viewed n.d., from https://www.statssa.gov.za/publications/P0318/P03182016.pdf Note: Area under ROC curve $=0.7095$.

ROC, receiver operating characteristic.

FIGURE 3: Receiver operating characteristic curve - Food security model.

TABLE 10: Livelihood strategies.

\begin{tabular}{lcc}
\hline Livelihood strategies & Frequency & $\mathbf{\%}$ \\
\hline None & 883 & 44.85 \\
No labour & 39 & 1.98 \\
Farming & 22 & 1.12 \\
Non-farming income & 1025 & 52.06 \\
\hline Total & $\mathbf{1 9 6 9}$ & $\mathbf{1 0 0 . 0 0}$ \\
\hline
\end{tabular}

Source: Based on information from: Statistics South Africa, 2016, General Household Survey, viewed n.d., from https://www.statssa.gov.za/publications/P0318/P03182016.pdf

in odds of being non-labour income-based household increasing by 1.026 times. On the other hand, high trusting households are 0.912 times more likely going to be nonlabour-based than non-farming-income-based. To trust 
individuals and institutions, you would have engaged with them several times, with that engagement likely to boost chances of engaging in high-value strategies.

Social capital has been seen to significantly boost the likelihood of engaging in non-labour incomes as well as in farming strategy compared with non-farming activities. The positive effect on non-labour strategy is counter-intuitive;

\section{TABLE 11: Variable description.}

\begin{tabular}{|c|c|}
\hline Variable & Description \\
\hline Strategy & $\begin{array}{l}\text { This is a categorical variable based on the main source of income } \\
\text { of the household. The categories are mainly: no source of income, } \\
\text { non-labour income, farm income and non-farm income (as in } \\
\text { General Household Survey above). }\end{array}$ \\
\hline $\begin{array}{l}\text { Deprivation } \\
\text { score }\end{array}$ & $\begin{array}{l}\text { This is a covariate computed from questionnaire item asking for } \\
\text { the household has failed to access basic goods and services such } \\
\text { as food, health and education. High score implies highly deprived. }\end{array}$ \\
\hline Trust score & $\begin{array}{l}\text { Households have been asked to indicate how much trust they have } \\
\text { in different individuals and/or institutions within the system } \\
\text { including family, neighbours and political leaders. A trust score was } \\
\text { then computed with high scores signifying more trust. }\end{array}$ \\
\hline Household size & This is the number of individuals with the household \\
\hline $\begin{array}{l}\text { Economic Active } \\
\text { members }\end{array}$ & $\begin{array}{l}\text { This is number of household members between the ages of } 16 \text { and } \\
64 \text { years. }\end{array}$ \\
\hline $\begin{array}{l}\text { Social grouping } \\
\text { member }\end{array}$ & $\begin{array}{l}\text { This is whether the household has a member who is part of a } \\
\text { social grouping such as Stokvel, burial society, etc. } 0=\text { No, } 1=\text { Yes. } \\
\text { This captures social capital. }\end{array}$ \\
\hline $\begin{array}{l}\text { Contacted local } \\
\text { leadership }\end{array}$ & $\begin{array}{l}\text { This measure whether the household has a member who has } \\
\text { contacted local leadership, or in the event of none, will the } \\
\text { respondent be willing and able to contact would the need arise. } \\
\text { The strength of institutions is tested. }\end{array}$ \\
\hline Migrant & $\begin{array}{l}\text { Whether the household has an individual who is away for more } \\
\text { than } 3 \text { months at a time }\end{array}$ \\
\hline Asset access & $\begin{array}{l}\text { This measures access to physical assets by households which } \\
\text { include access to cell phones, electrical stove and refrigerator } \\
\text { among other things. }\end{array}$ \\
\hline
\end{tabular}

Source: Based on information from: Statistics South Africa, 2016, General Household Survey, viewed n.d., from https://www.statssa.gov.za/publications/P0318/P03182016.pdf Note: The variables are in line with the GHS, 2016 as well as the literature (see Stifel 2010; Mishi \& Mudziwapasi 2014).

\section{TABLE 12: Summary statistics.}

\begin{tabular}{lccccc}
\hline Variable & Obs & Mean & Std. Dev. & Minimum & Maximum \\
\hline Household size & 1735 & 4.914121 & 2.923694 & 1 & 31 \\
Economically active & 1506 & 1.128818 & 1.137407 & 0 & 15 \\
Trust score & 1969 & 23.16811 & 5.069204 & 0 & 30 \\
Deprivation & 1969 & 6.67293 & 5.367272 & 0 & 30 \\
Assets access & 1969 & 10.65973 & 6.400585 & 0 & 29
\end{tabular}

Source: Programme to Support Pro-poor Policy Development (PSPPD II)-University of Fort Hare (UFH) Economics survey.

Note: Logistic regression as specified in Eqn 2 was conducted, and the results are presented in Table 12.

Obs, observations; Std. Dev., standard deviation. however, on farming only, it is as expected (farming is regarded high value and is critical in sustainability of households among predominantly rural population). Those who have contacted a local leader in the recent past have likelihoods 4.734 times higher for being relying on nonlabour income compared to non-farming income.

Migration seems to be used as a livelihood strategy, as households who have a migrant member are 2.149 times likely to rely on non-labour income (which will be mainly remittances) and such households are also 3.06 times more likely to engaging in farming (resource intensive) than being reliant on non-farming income (salaried job or business income). In this context, remittances, could be viewed as provided, need capital to engage in farming activities which most household cannot afford.

Lastly, greater access to assets makes the odds of being reliant on income 0.18 times higher than being engaged in non-farming activities like salaried job and business (which is more likely going to be engaging in high-value strategy of non-farming income than relying on handouts). On the other hand, such access increases the likelihood of engaging in farming activities by 1.03 times. This is as reported from the GHS (2016) data and in line with the SLF framework where access to assets is key for sustainability of livelihoods.

\section{Summary, conclusions and policy recommendations}

Based on the literature covered in this study, it is evident that poor people are the ones who rely mainly on agriculture and other livelihood strategies. Rich people, according to literature, run big businesses across nations. Centred on the results from other studies, it is also evident that the main reason why poor people suffer is that they do not get financial assistance from the government, and hence, some researchers have pointed out that the government should provide reasonable loans to rural households for them to start their livelihoods projects and improve their standard of living. Education, access to ICT and urban areas are among the most

TABLE 13: Logistic regression results.

\begin{tabular}{|c|c|c|c|c|c|c|c|c|}
\hline \multirow[t]{2}{*}{ Variables } & \multicolumn{2}{|c|}{ Non-labour } & \multicolumn{2}{|c|}{ RRR } & \multicolumn{2}{|c|}{ Farm only } & \multicolumn{2}{|c|}{ RRR } \\
\hline & Coefficient & Standard error & Coefficient & Standard error & Coefficient & Standard error & Coefficient & Standard error \\
\hline Deprivation score & $0.0264 * *$ & 0.0349 & $1.026 * *$ & 0.035 & 0.0589 & 0.0450 & - & - \\
\hline Trust score & $-0.0920 * *$ & 0.0428 & $0.912^{* *}$ & 0.039 & -0.0645 & 0.0574 & - & - \\
\hline Household size & -0.109 & 0.0860 & - & - & -0.0150 & 0.0824 & - & - \\
\hline Eco. Active members & $-1.949 * * *$ & 0.417 & $0.142 * * *$ & 0.060 & 0.164 & 0.178 & - & - \\
\hline Social grouping member & $1.644^{* *}$ & 0.679 & $5.18 * *$ & 3.525 & $2.016 *$ & 1.065 & $7.51 *$ & 7.99 \\
\hline Contacted local leadership & $1.555 * * *$ & 0.417 & $4.734 * * *$ & 1.975 & -0.222 & 0.780 & - & - \\
\hline Migrant & $0.765^{*}$ & 0.452 & $2.149 *$ & 0.972 & $1.120 * *$ & 0.550 & $3.06 * *$ & 1.69 \\
\hline Asset access & $-0.163^{* * *}$ & 0.047 & $0.18 * * *$ & 0.057 & $0.00308 * *$ & 0.00141 & $1.03 * *$ & 0.02 \\
\hline Constant & -0.902 & 1.202 & - & - & $-5.635 * * *$ & 1.621 & - & - \\
\hline Observations & 769 & - & - & - & 769 & - & - & - \\
\hline
\end{tabular}

Source: Programme to Support Pro-poor Policy Development (PSPPD II)-University of Fort Hare (UFH) Economics survey

Note: The model is fit with $\operatorname{LR} \mathrm{Chi}^{2}(16)$ of 94.95 ; Prob > chi ${ }^{2}$ of less than $1 \%$ and pseudo- $R^{2}$ of $23.4 \%$.

$\mathrm{RRR}$, relative risk ratios.

$*, p<0.1 ; * *, p<0.05 ; * * *, p<0.01$ 
important factors that influenced livelihood diversification. Based on the results, it is recommended that professional training, Internet access through phones and wireless and urbanisation should be enhanced to enable households to diversify their sources of income and thus improve food security for their family members.

\section{Acknowledgements}

Comments from participants at the Global Development Finance conference 18-20 October 2017 held in Somerset West are acknowledged. The views and any omissions in this article are those of the authors and not of the conference participants or conference organisers.

\section{Competing interests}

The authors have declared that no competing interests exist.

\section{Authors' contributions}

All authors contributed equally to this work.

\section{Ethical consideration}

This article followed all ethical standards for a research without direct contact with human or animal subjects.

\section{Funding information}

Funding for this research was obtained from the National Research Foundation (NRF) under Syden Mishi Grant UID:107401. Opinions expressed and conclusions arrived at in this study are those of the author and are not necessarily to be attributed to the NRF.

\section{Data availability statement}

Data sharing is not applicable to this article as no new data were created or analysed in this study.

\section{Disclaimer}

The views and opinions expressed in this article are those of the authors and do not necessarily reflect the official policy or position of any affiliated agency of the authors.

\section{References}

Aguilar, G.R. \& Sumner, A., 2020, 'Who are the world's poor? A new profile of global multidimensional poverty', World Development 126, 104716. https://doi. org/10.1016/j.worlddev.2019.104716

Alemu, Z.G., 2012, Livelihood strategies in rural South Africa: Implications for poverty reduction, Zarihun Gudeta Alemu, Foz do Iguacu.

Ashley, C. \& Carney, D., 1999, Sustainable livelihoods: Lessons from early experience, DFD, London.

Barrett, C.B., Reardon, T. \& Webb, P., 2001, 'Nonfarm income diversification and household livelihood strategies in rural Africa: Concepts, dynamics, and policy implications', Food Policy 26(4), 315-331. https://doi.org/10.1016/S03069192(01)00014-8

Barrett, C. \& Swallow, B.M., 2005, 'Dynamic poverty traps and rural livelihoods', in F. Ellis \& H.A. Freeman (eds.), Rural livelihoods and poverty reduction policies, pp. 16-28, Routledge, London, viewed 14 February 2020, from https://libserv5. pp. 16-28, Routledge, London, viewed 14 February 2020, from https://libserv5.
tut.ac.za:7780/pls/eres/wpgdocload.downloadfile?pflename=F1559246066/ MohamedSS.pdf
Blein, R., 2013, Agriculture in Africa: Transformation and outlook, viewed 11 November 2018, from https://www.un.org/en/africa/osaa/pdf/pubs/2013africanagricultures. pdf

Brown, D.R., Stephens, E.C., Oumac, J.O., Murithi, F.M. \& Barrette, C.B., 2006, 'Livelihood strategies in the rural Kenyan Highlands', African Journal of Agricultural and Resource Economics 1(1), 21-36.

Bryceson, D., 1996, 'Deagrarianization and rural employment in sub-Saharan Africa: A sectoral perspective', World Development 24(1), 97-111. https://doi. org/10.1016/0305-750X(95)00119-W

Carter, M. \& May, J., 1999, 'Poverty, livelihood and class in rural South Africa', World Development 27(1), 1-20. https://doi.org/10.1016/S0305-750X(98)00129-6

Chambers, R., 1997, Whose reality counts: Putting the first last, Intermediate Technology Publications, London.

Chambers, R. \& Conway, G., 1992, Sustainable Rural Livelihoods: Practical Concepts for the 21st Century, IDS Discussion Paper 296, Brighton, IDS, viewed n.d., from https://opendocs.ids.ac.uk/opendocs/handle/20.500.12413/775

Corral, L. \& Reardon, R., 2001, 'Rural non-farm incomes in Nicaragua', World Development 29(3), 427-442. https://doi.org/10.1016/S0305-750X(00)00109-1

Creswell, J.W., 2014, Research design. Qualitative, quantitative and mixed methods approaches, 4th edn., Sage Publications, Lincoln.

Department of Land Affairs (DoLA), 1997, Rural development framework, Rural Development Task Team \& Land Reform Policy Branch, viewed n.d., from http://www.ruraldevelopment.gov.za/phocadownload/White-Papers/ whitepaperlandreform.pdf

Eastern Cape Socio-Economic Consultative Council (ECSECC), 2017, Raymond Mhlaba local municipality socio economic review and outlook, 2017.

Eastern Cape NGO Coalition, 2012, Concept note for the sustainability in the context.

Ellis, F., 1998, 'Household strategies and rural livelihood diversification', The Journal of Development Studies 35(1), 1-38. https://doi.org/10.1080/00220389808422553

Ellis, F., 2000, Rural livelihoods and diversity in developing countries, Oxford University Press, Oxford.

Eneyew, A. \& Bekele, W., 2009, Livelihood strategies and its determinants in Southern Ethiopia, viewed 16 March 2017, from https://www.articlesbase.com/collegeandUniversity.

Gautam, Y. \& Andersen, P., 2016, 'Rural livelihood diversification and household wellbeing: Insights from Humla, Nepal', Journal of Rural Studies 44, 239-249. https:// doi.org/10.1016/j.jrurstud.2016.02.001

Groenewegen, J., Spithoven, A. \& Van den Berg, A., 2010, Institutional economics, In Introduction, Basingstoke (England), Palgrave Macmillan.

Hosu, S. \& Mushunje, A., 2013, 'Optimizing resource use and economics of croplivestock integration among small farmers in semiarid regions of South Africa', Agroecology and Sustainable Food System 37(9), 985-1000. https://doi.org/ 10.1080/21683565.2013.802755

Huber, F.K., Morlok, M., Weckerle, C.S. \& Seeland, K., 2015, 'Livelihood strategies in Shaxi, Southwest China: Conceptualizing mountain-valley interactions as a human-environment system', Sustainability 7(3), 3204-3229. https://doi. org/10.3390/su7033204

Huber, F.K., Yang, Y., Weckerle, C.S. \& Seeland, K., 2014, 'Diversification of livelihoods in a society in transition: A case study of Tibetan communities in Southwest China', Society \& Natural Resources 27(7), 706-723. https://doi.org/10.1080/08 941920.2014.901465

Hussein, K. \& Nelson, J., 1999, 'Sustainable livelihoods and livelihoods diversification', IDS Working Paper, no. 69, Institute of Development Studies, London.

International Labour Organization, 2018, World employment social outlook, International Labour Organization, viewed 17 June 2019, from https://www. ilo.org/wcmsp5/groups/public/---dgreports/---dcomm/---publ/documents/ publication/wcms_615594.pdf

Kassie, G.W., Kim, S. \& Fellizarjr, F.P., 2017, 'Determinant factors of livelihood diversification: Evidence from Ethiopia', Cogent Social Sciences 3, 1369490. diversification: Evidence from Ethiopia', Cogent
https://doi.org/10.1080/23311886.2017.1369490

Khatiwada, S.P., Deng, W., Paudel, B., Khatiwada, J.R., Zhang, J. \& Su, Y., 2017 'Household livelihood strategies and implication for poverty reduction in rural areas of Central Nepal', Sustainability 9(4), 612. https://doi.org/10.3390/ su9040612

Kremelberg, D., 2011, Practical statistics, Sage Publication, Los Angeles, CA.

Leibbrandt, M., Woolard, C. \& Woolard, I., 2000, 'The contribution of income components to income inequality in the rural former homelands of South Africa: A decomposable Gini analysis', Journal of African Economies 9(1), 79-99. https:// doi.org/10.1093/jae/9.1.79

Lloyd-Jones, T. \& Rakodi, C., 2002, Urban livelihoods: A people-centred approach to reducing poverty, Taylor and Francis.

Loison, S.A., 2015, 'Rural livelihood diversification in sub-Saharan Africa: A literature review', The Journal of Development Studies 51(9), 1125-1138. https://doi.org/ 10.1080/00220388.2015.1046445

Maniriho, A. \& Nilsson, P., 2018, 'Determinants of livelihood diversification among rwandan households: The role of education, ICT and Urbanization', East Africa Research Papers in Economics and Finance (EARP-EF), November 17, 2018, viewed n.d., from http://ju.se/download/18.243bd3a4161b08d 5c5817888/1520578313123/EARP-EF\%202018-24\%20Maniriho.pdf

Mathebula, J., Molokomme, M., Jonas, S. \& Nhemachena, C., 2017, 'Estimation of household income diversification in South Africa: A case study of three provinces', South African Journal Science 113(1/2), 1-9. https://doi. org/10.17159/sajs.2017/20160073 
Mathie, A. \& Cunningham, G., 2003, 'From clients to citizens: Asset-based community development as a strategy for community-driven development', Development in Practice 13(5), 474-486. https://doi.org/10.1080/0961452032000125857

Ministry of Rural Development and Land Reform (MoRDLR), 2009, The comprehensive rural development program framework, MoRDLR, Pretoria, viewed 17 June 2019, from http://www.ruraldevelopment.gov.za/phocadownload/Documents/crdp version1-28july09.pdf

Mishi, S. \& Mudziwapasi, L., 2014, 'Remittances and sustainability of family livelihoods: Evidence from Zimbabwe', Journal of Economics and Behavioral Studies 6(12) 958-973.

Mukotami, S., 2014, Rural households livelihood strategies in communities around the Fort Hare and Middle Drift rural dairy projects in Eastern Cape Province South Africa, viewed 30 August 2018, https://hdl.handle.net/20.500.11837/334

Munhenga, D., 2014, Determinants of rural households' diversification of livelihood strategies: A case of Intsika Yethu farmers of the Eastern Cape Province, South Africa, viewed 30 August 2018, from https://hdl.handle. net/20.500.11837/377

Nilsson, P., 2018, 'Spatial spillovers and households' involvement in the non-farm sector: Evidence from rural Rwanda', Regional Studies 53(5), 731-740. https:// doi.org/10.1080/00343404.2018.1482415

Organisation for Economic Co-operation and Development (OECD), 2008, Growing unequal? Income distribution and poverty in OECD countries, OECD publishers, Paris, viewed n.d., from https://read.oecd-ilibrary.org/social-issues-migrationhealth/growing-unequal_9789264044197-en\#page1

Organisation for Economic Co-operation and Development (OECD), 2011, Divided we stand: Why inequality keeps rising, OECD Publishers, Paris, viewed 07 May 2019, from http://www.oecd.org/fr/social/inegalite.htm

Rakodi, C. \& Lloyd-Jones, T. (eds.), 2002, Urban livelihoods: A people-centred approach to reducing poverty, Earthscan, London.

Reardon, T., Delgado, C. \& Matlon, P., 1992, 'Determinants and effects of income diversification among farm households of Burkina Faso', The Journal of Development Studies 28(2), 264-296. https://doi.org/10.1080/00220389208422232

Scoones, I., 2016, 'Livelihoods perspectives and rural development', The Journal of Peasant Studies 36(1), 171-196. https://doi.org/10.1080/03066150902820503

Simatele, M.C., Mishi, S., Tsegaye, A., Makhetha-Kosi, P., Kapingura M.F. \& Khumalo, S.A., 2016, Harnessing Livelihood Strategies for Pro-Poor Policy Intervention in Eastern Cape South Africa-The Programme to Support Pro-poor Policy Development (PSPPD II)-University of Fort Hare (UFH) Economics survey, The Presidency, South Africa.

Statistics South Africa, 2016, General household survey, viewed n.d., from https:// www.statssa.gov.za/publications/P0318/P03182016.pdf
Statistics South Africa, 2018, 'Statistical release quarterly labour force survey', Quarterly Labour Force Survey PO211(Quarter 2), 1-70. https://doi.org/10.1002/ Quarterly
stc. 2139

Stifel, D., 2010, 'The rural non-farm economy, livelihood strategies and household welfare', African Journal of Agricultural and Resource Economics 4(1), 82-109.

Swift, J., 1998, Factors influencing the dynamics of livelihood diversification and rural non-farm employment in space and time: Rural nonfarm employment project, Natural Resource Institute, Chataam.

Toyin, M.E. \& Mushunje, A., 2016, 'Income diversification and its determinants among households in Eastern Cape province, South Africa', Journal of Economics and Behavioural Studies 8(6), 19-27. https://doi.org/10.22610/jebs.v8i6(J).1480

United Nations Food and Agriculture Organisation (UN-FAO), 2013, Word food and Agriculture FAO: Statistical year book, viewed 06 May 2019, from https://www. fao.org/docrep/018/i3107e/i3107e.PDF

Urrehman, M.J. \& Mubina, F.R., 2008, 'Livelihood strategies of different categories of households in rural areas of Abbottabad, Pakistan', Sarhad Journal of Agriculture 24(4), 599-605.

Von Braun, J. \& Pandya-Lorch, R., 1991, 'Income sources of malnourished people in rural areas: Microlevel information and policy implications (No. 5)', International Food Policy Research Institute (IFPRI), viewed 07 May 2019, from https://ideas. Food Policy Research Institute
repec.org/p/fpr/ifprwp/5.html

Warren, P., 2002. Livelihoods diversification and enterprise development. An initial exploration of concepts and issues. Livelihood support program (LSP) working paper, 4. Food and Agriculture Organization of the United Nations, viewed 07 May 2019, from http://www.fao.org/tempref/docrep/fao/008/j2816e/j2816e00.pdf

Wilke, J., 2006, Understanding the asset-based approach to community development. CRP 381: Participatory Methods, viewed 01 June 2019, from http://citeseerx.ist. psu.edu/viewdoc/download?doi=10.1.1.513.3137\&rep=rep1\&type=pdf

World Bank, 2018a, GINI index (World Bank estimate), viewed 16 February 2019, from https://data.worldbank.org/indicator/SI.POV.GINI

World Bank, 2018b, Poverty headcount ratio at national poverty lines $\%$ of population), viewed 16 February 2019, from https://data.worldbank.org/ indicator/SI.POV.NAHC

World Bank, 2018c, Unemployment, total (\% of total labor force) (modeled ILO estimate), viewed 13 April 2019, from https://data.worldbank.org/indicator/SL.UEM.TOTL.ZS

Xu, D., Zhang, J., Rasul, G., Liu, S., Xie, F., Cao, M. et al., 2015, 'Household livelihood strategies and dependence in the mountainous settlements in the Three Gorges Reservoir Area, China', Sustainability 7(5), 4850-4869. https://doi.org/10.3390/ su7054850

Zerihun, G.A., 2012, 'Livelihood strategies in rural South Africa: Implications for poverty reduction', 2012 Conference, August 18-24, 2012, Foz do Iguacu, Brazil 125411 , International Association of Agricultural Economists. 